\title{
Pituitary Gonadotropin-releasing Hormone Receptors
}

\author{
EFFECTS OF CASTRATION, STEROID REPLACEMENT, AND THE ROLE \\ OF GONADOTROPIN-RELEASING HORMONE IN MODULATING RECEPTORS
}

\author{
IN THE RAT
}

\author{
M. S. Frager, D. R. Pieper, S. A. Tonetta, J. A. Duncan, and J. C. Marshall, \\ Department of Internal Medicine, Division of Endocrinology and Metabolism, \\ and Metabolism Research Unit, Reproductive Endocrinology Program, \\ University of Michigan, Ann Arbor, Michigan 48109
}

\begin{abstract}
A B S T R A C T To study the role of gonadotropin-releasing hormone $(\mathrm{GnRH})$ receptors in the regulation of gonadotropin secretion, we used $\mathrm{D}^{-125} \mathrm{I}_{\text {-alanine }}$ des $_{6}$

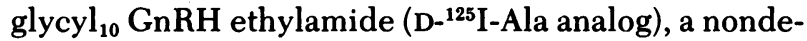
gradable, superagonist $\mathrm{GnRH}$ analog to assess $\mathrm{GnRH}$ receptors on rat pituitary membranes. Receptor affinity in intact adult rats was $5.0 \times 10^{9} \mathrm{M}^{-1}$ and was unchanged after castration in both sexes. Castration of adult male and female rats produced a twofold increase in GnRH binding capacity by $7 \mathrm{~d}$ and binding capacity remained elevated for the subsequent $14 \mathrm{~d}$. GnRH receptor number rose more rapidly after castration in males than females, and the time-course of receptor rise was similar to the increase in serum gonadotropin levels. The increase in GnRH binding capacity was prevented by gonadal steroid replacement at the time of castration in both sexes. Injections of the $\mathrm{GnRH}$ analog, $\mathrm{D}-\mathrm{Ser}_{6}(\mathrm{TBu})$ des $\mathrm{Gly}_{10} \mathrm{GnRH}$ ethylamide for $4 \mathrm{~d}$ produced a $70 \%$ increase in $\mathrm{GnRH}$ receptor number in intact male rats and testosterone-replaced castrates. The same regimen, however, failed to increase the elevated receptor numbers present after castration. Administration of rabbit anti-GnRH serum concomitant with castration inhibited the rise in both $\mathrm{GnRH}$ receptor number and luteinizing hormone. The changes in pituitary GnRH receptors parallel previously demonstrated changes in hypothalamic secretion of GnRH. Thus, GnRH probably regulates its own receptor in vivo and gonadal steroids may influence pituitary GnRH receptors by changing hypothalamic GnRH secretion.
\end{abstract}

This work was presented in part at the 37th Annual Meeting of the American Federation of Clinical Research, in Washington, D. C., 10-12 May 1980.

Received for publication 21 July 1980 and in revised form 24 October 1980

\section{INTRODUCTION}

Changes in serum gonadotropins after castration and steroid replacement have been extensively documented (1-3). However, the precise mechanisms responsible for the gonadotropin rise after castration and the role and relative effects of gonadal steroids at different sites in the hypothalamic-hypophyseal axis have not been completely elucidated. Pituitary secretion of gonadotropins is regulated by gonadotropin-releasing hormone $(\mathrm{GnRH})^{1}$ and gonadal steroids could act on the hypothalamus to change GnRH synthesis and secretion, on the pituitary to modify responsiveness to $\mathrm{GnRH}$, or have effects at both sites. Clear evidence is available that gonadal steroids modulate gonadotropin responses to GnRH in vivo; castration enhances and androgens inhibit gonadotropin secretion following GnRH administration to male rats (4). Estrogens have a biphasic effect in female rats, initially inhibiting and later enhancing luteinizing hormone ( $\mathrm{LH})$ responses to $\operatorname{GnRH}(5,6)$. Also, gonadotropin secretion after GnRH varies during both the rat estrous cycle (7-11) and the menstrual cycle in women $(12,13)$.

More recent studies $(14,15)$ have demonstrated increased levels of $\mathrm{GnRH}$ in pituitary stalk blood in ovariectomized rhesus monkeys, and this increased GnRH secretion could be responsible for the elevation of gonadotropins after castration. Sarkar et al. (16) found elevated pituitary stalk plasma $\mathrm{GnRH}$ concentrations at the time of the proestrus LH surge in rats and the same group recently reported increased GnRH concentrations in pituitary stalk plasma 4 and $28 \mathrm{~d}$ following

\footnotetext{
${ }^{1}$ Abbreviations used in this paper: BSA, bovine serum albumin; FSH, follicle-stimulating hormone; GnRH, gonadotropin-releasing hormone; LH, luteinizing hormone.
} 
ovariectomy and adrenalectomy (17). Other studies have shown that orchidectomy reduced and subsequent testosterone or estradiol replacement restored hypothalamic $\mathrm{GnRH}$ content to normal in male rats (18-20). These data suggest that gonadal steroids influence either hypothalamic synthesis or release of $\mathrm{GnRH}$. In vitro studies with rat pituitaries or cultured anterior pituitary cells have demonstrated that estrogens enhance $(21-23)$ and androgens inhibit $(23,24)$ sensitivity to $\mathrm{GnRH}$.

Changes in pituitary responsiveness to $\mathrm{GnRH}$ could be explained in part by changes in $\mathrm{GnRH}$ receptor number because $\mathrm{GnRH}$, like other polypeptide hormones, acts by initially binding to specific receptors on the surface of the target tissue. Thus, factors such as gonadal steroids that influence pituitary responsiveness to GnRH could conceivably exert their action by altering the number of receptors for GnRH on the surface of the gonadotroph (25).

Previous studies (26-28) using native $\mathrm{GnRH}$ as ligand have demonstrated the presence of two GnRH binding sites, one with high capacity but low affinity, and another with high affinity and low capacity that probably represents the physiologically important $\mathrm{GnRH}$ receptor. Since most of the binding is to the low affinity site, changes in characteristics of the high affinity site were difficult to measure accurately (25). In this study, we assessed pituitary GnRH receptors using a superagonist $\mathrm{GnRH}$ analog, D-alanine ${ }_{6}$ des glycyl $_{10} \mathrm{GnRH}$ ethylamide (D-Ala analog) as ligand. We have previously demonstrated that the D-Ala analog binds to a single class of receptors that apparently are the same sites involved in the high affinity interaction with $\mathrm{GnRH}$ (29). In addition, superagonist $\mathrm{GnRH}$ analogs are resistant to degradation by pituitary membranes and cytosol (30), and thus use of the D-Ala ana$\log$ avoids the problems of tracer degradation seen with native GnRH (31).

The following studies were performed to delineate changes in the number and affinity of pituitary membrane GnRH receptors after castration and steroid replacement in adult rats. We hoped to ascertain if changes in these receptors could be involved in the regulation of gonadotropin secretion, and to examine factors controlling $\mathrm{GnRH}$ receptors.

\section{METHODS}

GnRH and $\left\{\right.$ D-serine ${ }_{6}$ (TBu) $\}$ des $\mathrm{Gly}_{10} \mathrm{GnRH}$ ethylamide (D-Ser analog) were gifts from Dr. M. Von der Ohe (Hoechst A. G., Frankfurt, West Germany). D-Ala ${ }_{6}$ des Gly I0 $_{10}$ GnRH ethylamide (D-Ala analog) was a gift from Dr. J. Rivier and Dr. W. W. Vale of the Salk Institute, San Diego, Calif. D- ${ }^{125}$ I-Ala analog was prepared using the lactoperoxidase-glucose oxidase method as previously described (32). Rabbit antiGnRH serum (33) and normal rabbit serum were kindly provided by Dr. R. P. Kelch. Bovine serum albumin (BSA) was obtained from Miles Laboratories, Inc., Elkhart, Ind. All other chemicals were of reagent quality.

Adult Holtzman rats weighing 225-250 g were maintained on a 14-h light/10-h dark cycle and allowed free access to food and water. Rats were castrated under ether and methoxyflurane anesthesia. Control animals were anesthetized, sham operated, and killed in an identical manner to castrated rats. In studies of steroid replacement, silastic implants filled with crystalline testosterone or estradiol were implanted subcutaneously at the time of castration. Two implants, 0.062 in. ID and $0.0125 \mathrm{in}$. OD and $10.5 \mathrm{~mm}$ in length were used for each animal. Details of the timing of different manipulations are given in Results.

After decapitation, pituitary glands were removed and the anterior pituitary was placed in $0.25 \mathrm{M}$ sucrose, frozen in ethanol-dry ice, and stored at $-85^{\circ} \mathrm{C}$ before use in the binding assay. For use in a binding study, pituitaries were thawed on ice and homogenized by hand in $0.25 \mathrm{M}$ sucrose using a ground glass homogenizer (10 strokes). The homogenate was centrifuged at $300 \mathrm{~g}$ for $5 \mathrm{~min}$ at $4^{\circ} \mathrm{C}$, and the resulting supernate centrifuged at $10,800 \mathrm{~g}$ for $20 \mathrm{~min}$. The $10,800 \mathrm{~g}$ pellet was washed three times in $10 \mathrm{mM}$ Tris buffer, and then resuspended to a dilution of $100 \mu \mathrm{g}$ protein $/ \mathrm{ml}$. $200 \mu \mathrm{l}$ of this crude membrane preparation was added to BSA-precoated polypropylene tubes containing assay buffer $(10 \mathrm{mM}$ Tris buffer $+1 \mathrm{mM}$ dithiothreitol $+0.5 \% \mathrm{BSA}$ ), varying amounts of unlabeled D-Ala analog, and $15-20$ pg of D-125I-Ala analog. The total incubation volume was $500 \mu \mathrm{l}$. After preliminary studies showed that binding was maximal at 40-60 min, the assay mixture was incubated for $1 \mathrm{~h}$ at $4^{\circ} \mathrm{C}$. Receptor bound hormone was separated by centrifugation at $27,000 \mathrm{~g}$ for $15 \mathrm{~min}$ at $4^{\circ} \mathrm{C}$. The supernate was aspirated and the pellet counted. Using this system and membranes from intact rats, $8-15 \%$ of added tracer was bound in the absence of unlabeled hormone. Nonspecific binding was assessed in the presence of $20 \mathrm{ng}$ of unlabeled hormone and was 1.5-2\% of total added counts. Determination of protein content of the membrane preparation was performed by the method of Lowry (34). Receptor affinity and binding capacity, expressed as femtomoles of analog bound per milligram membrane protein, were calculated from Scatchard (35) analysis of the competition data. Since GnRH receptor affinity was unchanged in different physiologic situations, later determinations of binding capacity were performed by saturation analysis. A near saturating amount of D-Ala analog (800 pg D-Ala analog and $200 \mathrm{pg} \mathrm{D-125}$ I-Ala analog) was incubated with $15-20 \mu \mathrm{g}$ membrane protein as described above and the amount of bound hormone calculated. Studies using three different iodinated preparations showed that 55 to $63 \%$ of added $\mathrm{D}^{-125} \mathrm{I}-\mathrm{Ala}$ analog bound to an excess of membrane protein. Thus, a value of $60 \%$ of added counts was used in the calculation of all binding capacities and affinities. $\mathrm{LH}$ and follicle-stimulating hormone (FSH) were measured by radioimmunoassay using standard National Institutes of Arthritis, Metabolism, and Digestive Diseases rat $\mathrm{LH}$ reagents and RP-1 as standard (36). Testosterone and estradiol were measured by radioimmunoassay as previously described $(37,38)$.

Statistical analysis was done using analysis of variance or Student's $t$ test, as appropriate.

\section{RESULTS}

Assay characterization. Incubating membranes from freshly prepared or frozen pituitary glands with tracer and unlabeled D-Ala analog resulted in identical competition curves. Additionally, the number of GnRH 
receptors was not changed by storage at $-85^{\circ} \mathrm{C}$ for up to 4 mo and all subsequent studies were performed using frozen pituitary glands.

The specific activity of $\mathrm{D}^{-125} \mathrm{I}-\mathrm{Ala}$ analog was assessed by self-displacement in a radioreceptor assay. Binding of serial dilutions of tracer alone was parallel to that using small amounts of tracer ( $15 \mathrm{pg}$ ) and increasing amounts of unlabeled hormone. The specific activity of D-125I-Ala analog was determined for each tracer preparation and ranged from 740 to $1,300 \mu \mathrm{Ci} / \mu \mathrm{g}$ (calculated using $100 \%$ of added counts).

The specificity of analog binding to the pituitary membrane preparation is shown in Fig. 1. Only somatostatin and arginine vasopressin inhibited tracer binding when present in $1-\mu \mathrm{g}$ amounts. To validate the saturation analysis, the binding capacity calculated from Scatchard analysis of competition curves was compared to that estimated by saturation analysis. Using a pool of membranes from intact male rats, the binding capacity from Scatchard analysis was $727 \pm 33.9$ (SEM) $\mathrm{fm} / \mathrm{mg}$ protein. Saturation analysis of binding to the same membrane preparation $(n=6)$ gave a binding capacity of $781 \pm 50.1$ (SEM). Thus, good agreement was obtained between the two methods and saturation analysis was used for subsequent studies. Intraassay variability was assessed by repeated determination using aliquots from a pool of a single preparation of pituitary membranes. The coefficient of variation was $15.1 \%$ for pituitaries from intact male rats and $13.3 \%$ for male castrates. Interassay variability was not directly determined, since in contrast to results using whole pituitary glands, storage of the 10,800-g crude mem-

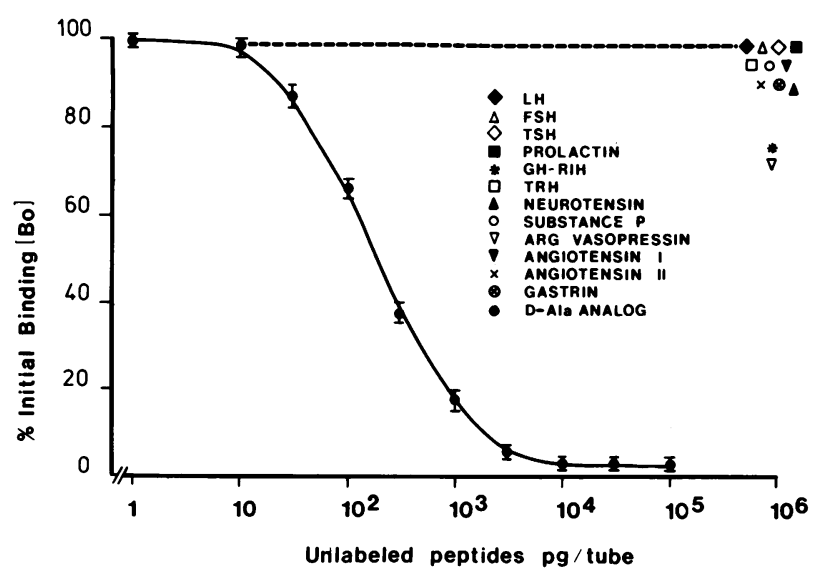

FIGURE 1 D-125I-Ala analog binding to intact male pituitary membranes in the presence of $1 \mu \mathrm{g}$ of various bioactive peptides (mean of triplicate determinations) or increasing amounts of unlabeled D-Ala analog (mean $\pm S E$ for six experiments). Nonspecific binding has been subtracted from each point. TSH, thyroid-stimulating hormone; TRH, thyrotropinreleasing hormone, GH-RIH, somatostatin. brane fraction resulted in decreasing estimates of binding capacity with time.

Studies after castration and steroid replacement. Competition curves and Scatchard analyses of analog binding to membranes from rats castrated $7 \mathrm{~d}$ previously and intact male controls are shown in Fig. 2. Receptor affinity was $5.0 \times 10^{9} \mathrm{M}^{-1}$ for intact controls and $5.6 \times 10^{9} \mathrm{M}^{-1}$ for castrated animals; binding capacity was $844 \mathrm{fm} / \mathrm{mg}$ protein for controls and $2,120 \mathrm{fm} / \mathrm{mg}$ for castrates. In other studies using saturation analysis the binding capacity in intact males was $756 \pm 41$ (SE) $\mathrm{fm} / \mathrm{mg}(n=25)$ and $1,578 \pm 74$ in males castrated for $1 \mathrm{wk}(n=17)$.

GnRH binding capacity, serum LH, and serum testosterone of male rats castrated 7, 14, and $21 \mathrm{~d}$ previously, and intact controls are shown in Fig. 3. Orchidectomy resulted in a doubling of $\mathrm{GnRH}$ binding capacity by $7 \mathrm{~d}$ that remained unchanged over the subsequent 14 d. GnRH binding capacity in castrated animals was significantly higher than in intact controls $(P<0.01$ at $7 \mathrm{~d}$; $P<0.001$ at 14 and $21 \mathrm{~d}$ ). Serum testosterone was low after castration; however, the values at $21 \mathrm{~d}$ were lost in a laboratory accident.

Experiments were performed to determine the early time-course of changes in GnRH binding capacity, gonadotropins, and gonadal steroids following castration. Adult male rats were castrated and killed at intervals from $4 \mathrm{~h}$ to $7 \mathrm{~d}$ later. Sham-operated controls were anesthetized and decapitated in an identical manner and results for male rats are shown in Fig. 4. In the controls, serum testosterone remained constant and was $4.2 \pm 0.38$ and $3.77 \pm 0.67 \mathrm{ng} / \mathrm{ml} 4 \mathrm{~h}$ and $7 \mathrm{~d}$ after sham operation. Serum testosterone was $0.3 \pm 0.08 \mathrm{ng} / \mathrm{ml} 4 \mathrm{~h}$
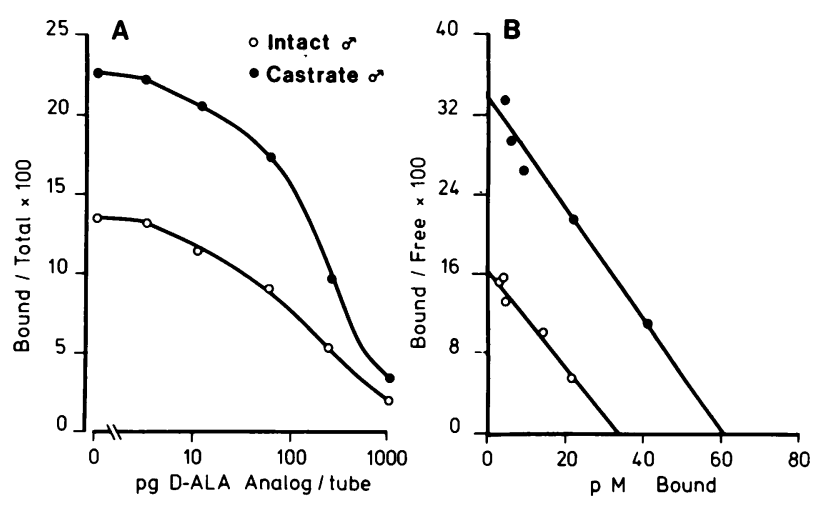

FIGURE 2 (A) Competition curves of D-125I-Ala analog binding to pituitary membranes from intact or $1 \mathrm{wk}$ castrate male rats (mean of triplicate determinations). Nonspecific binding has been subtracted (membrane protein/tube was $19.6 \mu \mathrm{g}$ in intact and $14.2 \mu \mathrm{g}$ in castrates). (B) Scatchard analysis of binding curves shown on the left showing similar receptor affinity in both intact $\left(5.0 \times 10^{9} \mathrm{M}^{-1}\right)$ and 1 -wk castrate $\left(5.6 \times 10^{9} \mathrm{M}^{-1}\right)$ rats. 

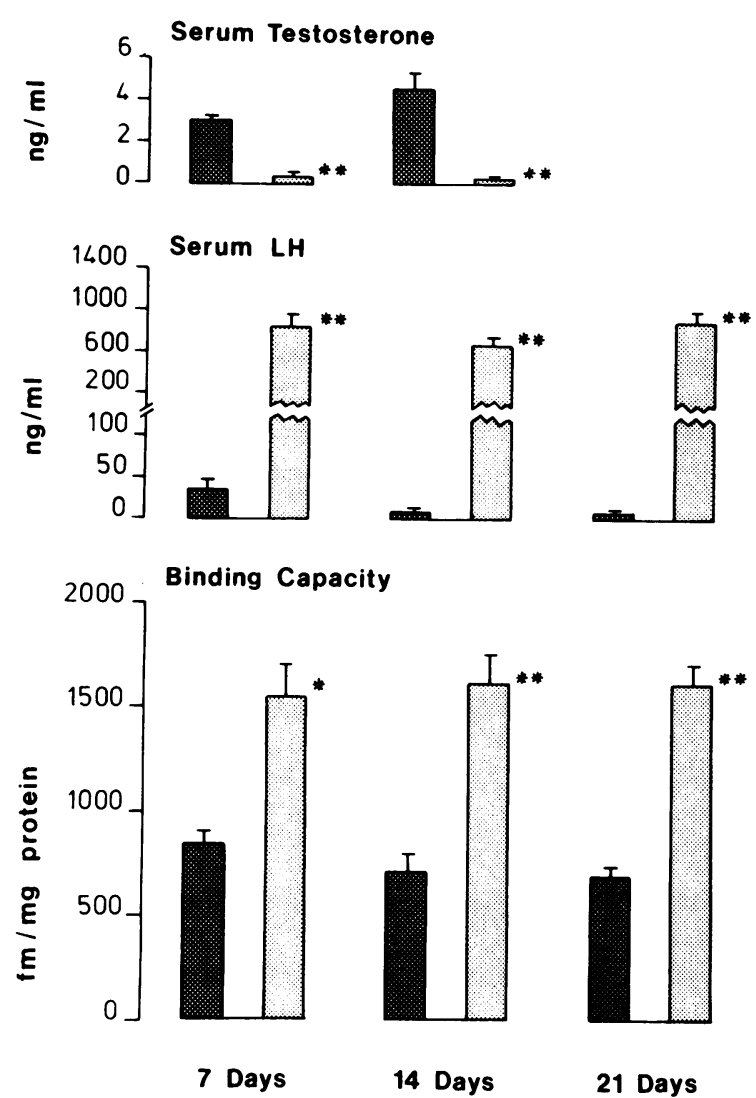

FIGURE 3 Serum testosterone, luteinizing hormone and $\mathrm{GnRH}$ binding capacity in adult male rats orchidectomized 7 , 14 , and $21 \mathrm{~d}$ previously and intact controls. (Mean $\pm \mathrm{SE}$ of six determinations. $)(* P<0.01, * * P<0.001)$. 8 , intact; castrate.

after orchidectomy and remained low thereafter. Serum LH rose rapidly and was elevated $(P<0.00001)$ by $8 \mathrm{~h}$ after castration; serum FSH was increased $(P<0.00005)$ $16 \mathrm{~h}$ after castration. GnRH binding capacity also increased rapidly after castration and was elevated at 16 $\mathrm{h}(P<0.05)$. Thereafter, binding capacity rose gradually during the $7 \mathrm{~d}$.

Similar studies were performed in 4-d cycling female rats killed between 0800 and 1200 hours on estrus or metestrus (cycle stage assessed by vaginal smears) and the results are also shown in Fig. 4. Sham-operated females were not studied because cycling female rats exhibit a threefold fluctuation of GnRH binding capacity during the estrous cycle (binding capacity is increased on diestrus and proestrus) and are therefore inappropriate controls (39). For this reason, statistical comparisons were made to intact cycling females, killed at the same times on estrus $(n=2)$ or metestrus $(n=3)$. Values for these control animals were: GnRH binding capacity, $386.4 \pm 11.2 \mathrm{fm} / \mathrm{mg}$; LH, $27.8 \pm 2.4 \mathrm{ng} / \mathrm{ml}$; FSH, 296.4 $\pm 73.2 \mathrm{ng} / \mathrm{ml}$. As previously reported (1), serum LH rose more slowly after castration in females and was not increased until $48 \mathrm{~h}$ after ovariectomy $(P<0.05)$. Serum FSH was also increased at $48 \mathrm{~h}(P<0.05)$. GnRH binding capacity also increased more slowly in females, and was not elevated until $48 \mathrm{~h}$ after ovariectomy $(P<0.05)$. Thereafter, GnRH binding capacity rose to approximately twice the 4 -h value at $7 \mathrm{~d}$, the same percentage increase as seen in males following orchidectomy.

The effects of testosterone replacement with orchidectomy are shown in Fig. 5. Rats received subcutaneous testosterone implants at the time of castration 7 or $14 \mathrm{~d}$ before death. Control rats received identical implants with sham operation. Testosterone replacement prevented the rise in serum $\mathrm{LH}$ and GnRH binding capacity seen $7 \mathrm{~d}$ after castration. In the animals killed $14 \mathrm{~d}$ after orchidectomy, serum testosterone was reduced $(P<0.05)$ and serum LH and GnRH binding capacity increased to levels intermediate between those seen in castrated and intact rats. Serum $\mathrm{LH}$ was elevated compared with intact and 7-d testosteronereplaced castrate rats $(P<0.05)$. GnRH binding capacity was also increased $(P<0.05)$ compared with $7-\mathrm{d}$ testosterone-replaced castrate rats.

Similar studies were performed in female rats. Receptor affinity was unchanged in cycling females, castrate and castrates replaced with estradiol, and was similar to that found in males $\left(K_{\mathrm{a}}=4-5.4 \times 10^{9} \mathrm{M}^{-1}\right)$. In females at random stages of the cycle, binding capacity was $465 \mathrm{fm} / \mathrm{mg}$ serum $\mathrm{LH} 31 \pm 2.1 \mathrm{ng} / \mathrm{ml}$ and estradiol $12 \pm 44 \mathrm{pg} / \mathrm{ml} .21 \mathrm{~d}$ after castration, GnRH binding capacity had doubled to $966 \mathrm{fm} / \mathrm{mg}$, and serum LH was $1,747 \pm 65 \mathrm{ng} / \mathrm{ml}$ and estradiol $2.4 \pm 0.2 \mathrm{pg} / \mathrm{ml}$. This marked increase in binding capacity was not seen in females who received estradiol implants at the time of castration, and binding capacity was $552 \mathrm{fm} / \mathrm{mg}$ where serum LH was $<1.0 \mathrm{ng} / \mathrm{ml}$ and estradiol $33.2 \pm 0.7$ $\mathrm{pg} / \mathrm{ml}$.

Studies using GnRH analogs and anti-GnRH sera. To test the hypothesis that increased endogenous GnRH secretion may be a causative factor in the rise in GnRH receptors after castration, animals were treated with a GnRH analog or anti-GnRH sera. Intact male controls and l-wk castrated rats with and without testosterone replacement were injected subcutaneously with $40 \mathrm{ng}$ D-Ser analog or BSA every $8 \mathrm{~h}$ for $4 \mathrm{~d}$, the last dose being given $10 \mathrm{~h}$ before death. We have previously shown that using this injection schedule doses $>2 \mu \mathrm{g}$ of GnRH or $15 \mathrm{ng}$ of D-Ser analog produce a $70 \%$ increase in $\mathrm{GnRH}$ binding capacity (40). As shown in Fig. 6, GnRH binding capacity increased in both intact controls and testosterone replaced castrates after 4 $\mathrm{d}$ of analog injections $(P<0.005)$. In contrast, binding capacity was unchanged in rats orchidectomized $7 \mathrm{~d}$ previously without gonadal steroid replacement. The 
MALES
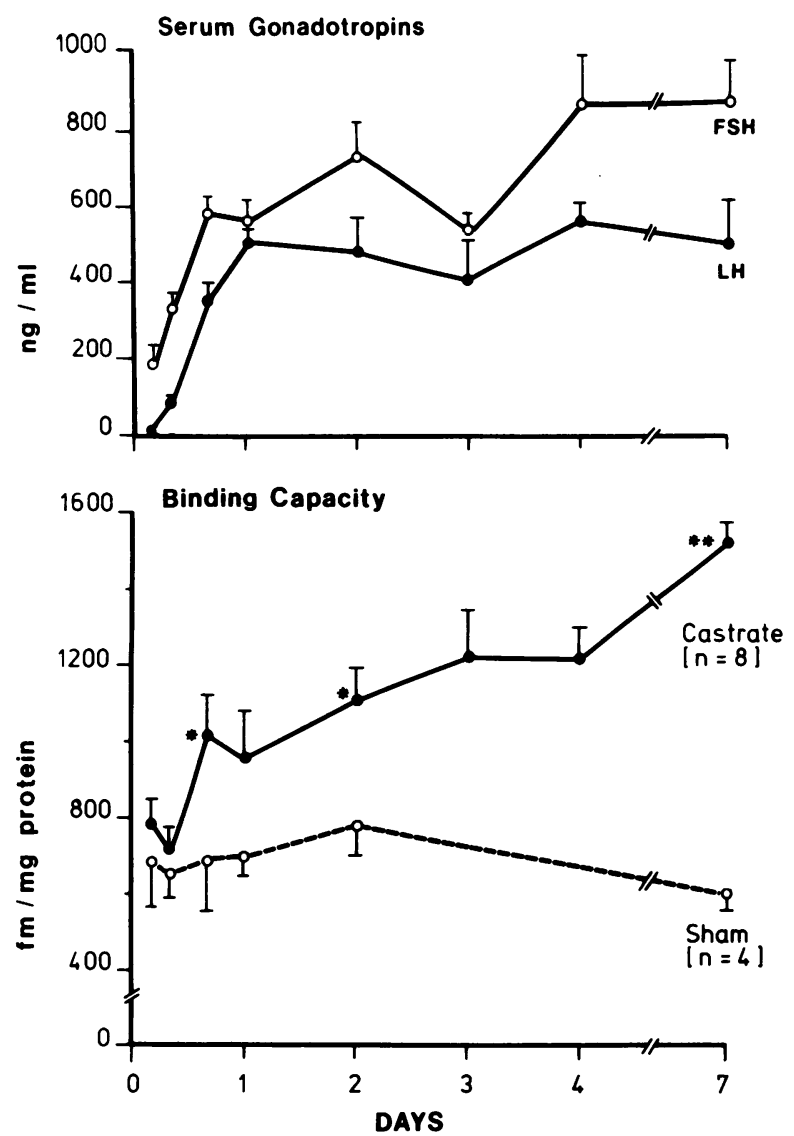

FEMALES
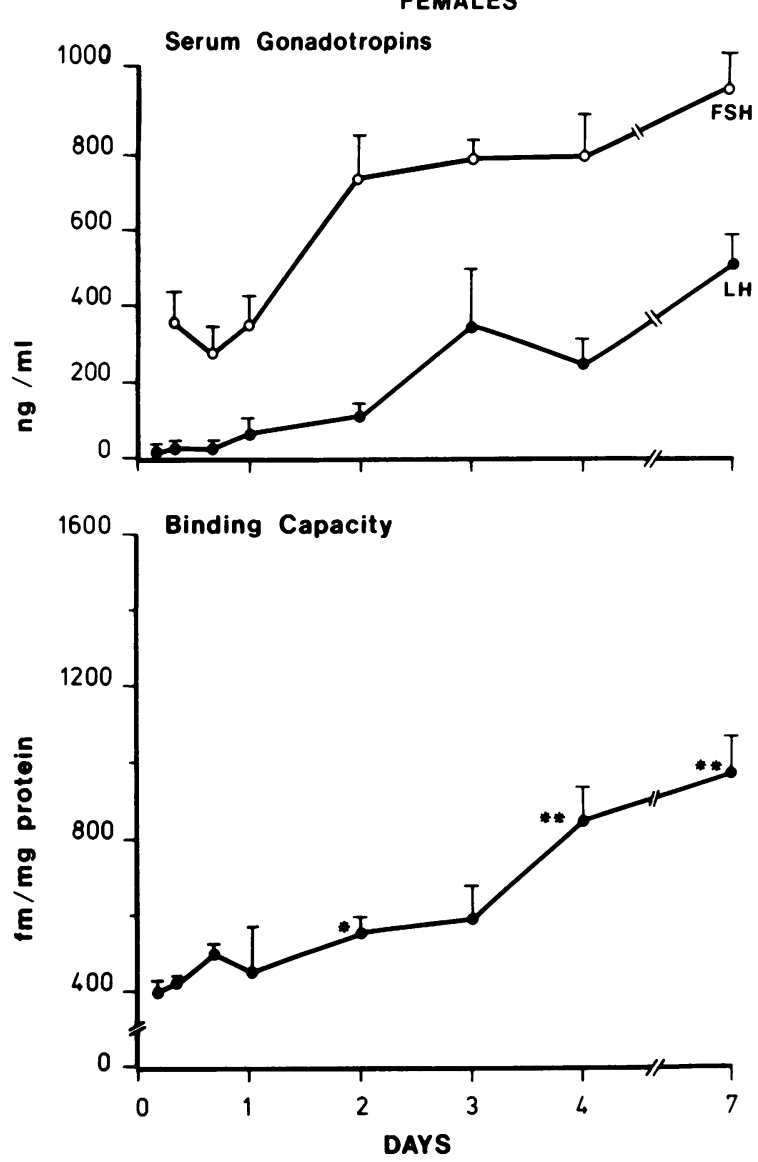

FIGURE 4 Time-course of changes in serum gonadotropins and GnRH binding capacity after castration in adult male rats (Mean $\pm S E ; n=8$ at each time point; ${ }^{* P}<0.05 ; * * P<0.0001$ ) in the left panel, and in adult females castrated on estrus or diestrus in the right panel $(n=4$; $* P<0.05 ; * * P<0.005)$.

BSA-injected castrate animals with steroid replacement had lower $\mathrm{GnRH}$ binding capacity than intact rats given BSA injections $(P<0.05)$.

Serum $\mathrm{LH}$ was $14.1 \pm 2.6$ and $19.6 \pm 3.7 \mathrm{ng} / \mathrm{ml}$ for intact rats treated with BSA and D-Ser analog $(=N S)$; $460 \pm 69$ and $315 \pm 38$ for castrated rats, $(=N S)$; and 9.3 \pm 1.9 and $7.6 \pm 1.4$ for testosterone replace castrates (=NS).

In additional studies, rabbit anti-GnRH serum M-13 was administered to adult male rats at the time of castration. It has previously been reported that this antibody is specific for amino acids $4-10$ of native GnRH and that $0.5 \mathrm{ml}$ of the antisera has a binding capacity for $\mathrm{GnRH}$ of $4.3 \mu \mathrm{g} / \mathrm{ml}$ (33). Antisera and normal rabbit serum were diluted with equal volumes of saline and $0.5 \mathrm{ml}$ was given intraperitoneally at the time of castration at 0800 hours on day 1 . Subsequently, $0.25 \mathrm{ml}$ was injected intraperitoneally at 0800 hours on days 2-4 and again $10 \mathrm{~h}$ before death on the morning of day
5. The results shown in Fig. 7 indicate that normal rabbit serum treatment did not have an effect on serum LH or GnRH binding capacity compared with castrate rats. Treatment with rabbit anti-GnRH serum markedly reduced the rise in serum $\mathrm{LH}$ and binding capacity seen in normal rabbit serum treated castrates $(P$ $<0.005)$. The anti-GnRH-treated castrate rats, however, had higher serum LH and binding capacity ( $P$ $<0.05)$ than intact controls.

\section{DISCUSSION}

In this paper we have characterized a sensitive and specific assay for assessment of $\mathrm{GnRH}$ receptors using a nondegradable, superagonist $\mathrm{GnRH}$ analog as ligand. The method used differs from earlier studies of native GnRH binding to pituitary membranes in that only high affinity binding sites are demonstrated. This allows accurate assessment of the high affinity site that 


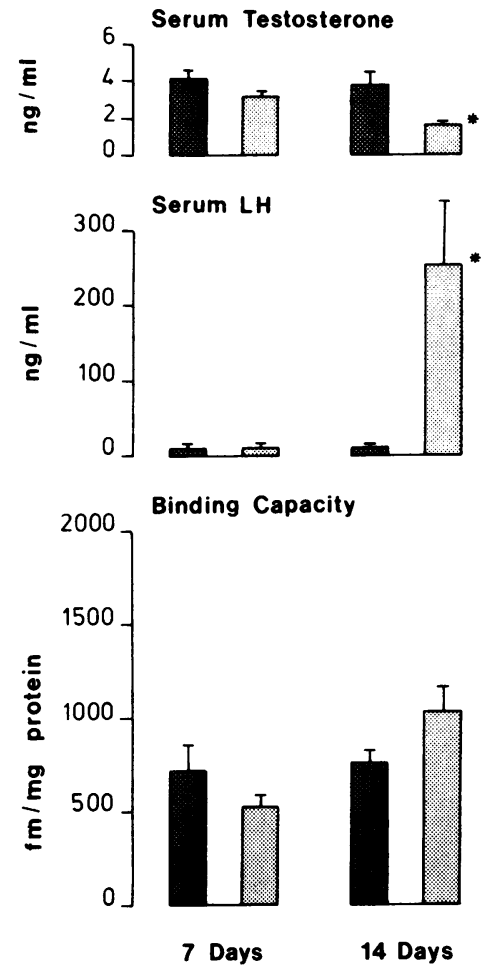

Figure 5 Effects of subcutaneous testosterone implants placed in adult male rats at the time of castration (ख) or sham operation ( $\Theta)$ on $\mathrm{LH}$ and $\mathrm{GnRH}$ binding capacity after 7 and $14 \mathrm{~d}($ Mean $\pm \mathrm{SE} ; n=6)(* P<0.05)$.

presumably represents the biologically important GnRH receptor.

With this method we have demonstrated that $\mathrm{GnRH}$ receptor number increased strikingly following castration without change in receptor affinity. In males $\mathrm{GnRH}$ binding capacity increased rapidly between 8 and $16 \mathrm{~h}$ after orchidectomy, and continued to rise gradually for $7 \mathrm{~d}$; there was no further change in receptor number during the subsequent $14 \mathrm{~d}$. Serum $\mathrm{LH}$ rose more quickly and was significantly increased over shamoperated controls $8 \mathrm{~h}$ after orchidectomy. Serum FSH was first elevated $16 \mathrm{~h}$ after castration and continued to rise gradually, whereas serum LH plateaued at $24 \mathrm{~h}$. The reasons for these different patterns of gonadotropin and GnRH receptor rise are not clear, but may be related to testosterone feedback on the hypothalamus and pituitary.

Using castrated male rats whose endogenous $\mathrm{GnRH}$ secretion was blocked with phenobarbital, Nansel et al. $(41,42)$ replaced $\mathrm{GnRH}$ in a pulsatile manner designed to mimic events following castration without phenobarbital treatment. Comparing these phenobarbitaltreated castrates to identical animals with dihydrotestosterone replacement, these authors demonstrated that the initial $\mathrm{LH}$ rise within $8 \mathrm{~h}$ after orchidectomy was due to enhancement of pituitary sensitivity to the self-priming effects of GnRH. This early effect was shown to be a direct action of testosterone withdrawal on the pituitary and was fully manifest $6-8 \mathrm{~h}$ after castration. We have found that serum LH rises more quickly than $\mathrm{GnRH}$ receptors after castration. The rapid, initial rise of serum LH could be explained in part by this direct effect of testosterone withdrawal on the pituitary. Within $16 \mathrm{~h}$ following castration both serum gonadotropin and GnRH increase sharply. This occurs after the direct effect of testosterone is fully manifest, and hypothalamic secretion of GnRH may increase at this time.

The time-course of GnRH receptor increase and gonadotropin elevation following ovariectomy is clearly different to that following orchidectomy. GnRH binding capacity and gonadotropins rise more slowly and are not significantly elevated until $48 \mathrm{~h}$ after ovariectomy. This parallel rise in serum gonadotropins and $\mathrm{GnRH}$ binding capacity suggests that both are responding to increased hypothalamic secretion of GnRH. Both Neill et al., and Carmel et al. $(14,15)$ have found

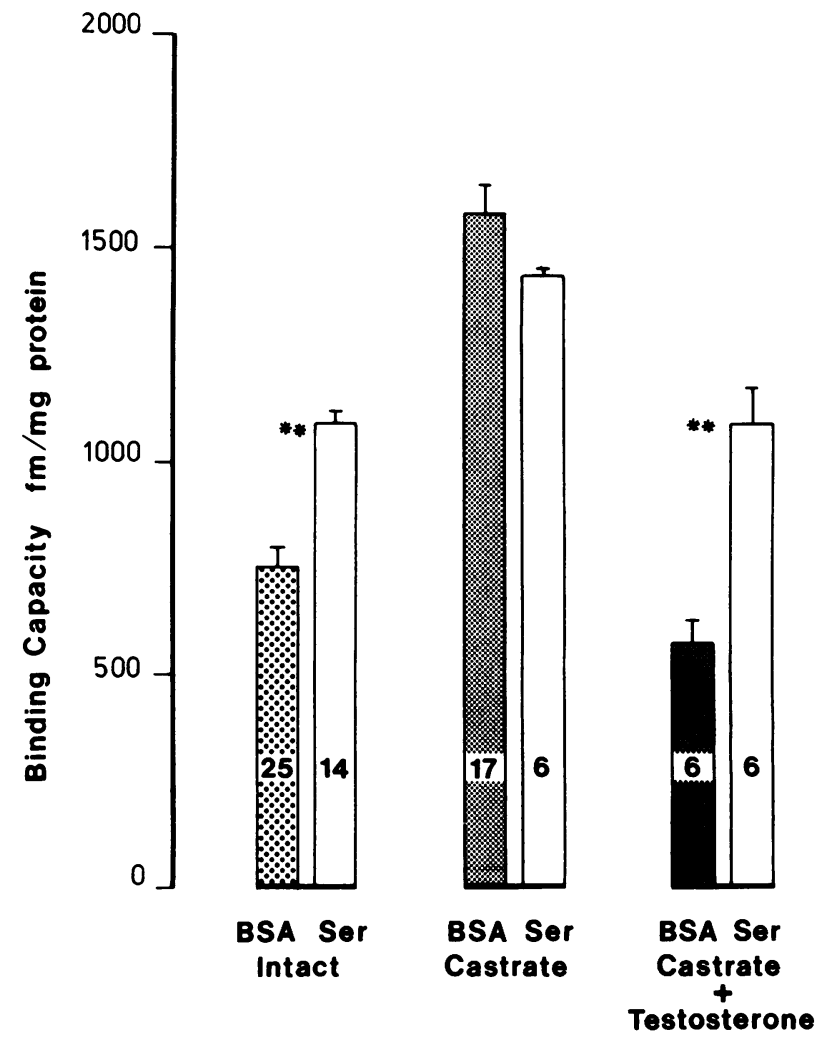

FIGURE 6 Effects of D-Ser analog injections on GnRH binding capacity in adult male rats. Rats were castrated or shamoperated and some received subcutaneous testosterone implants at the time of operation. $7 \mathrm{~d}$ later, animals received either $0.1 \%$ BSA or $40 \mathrm{ng} \mathrm{D}-\mathrm{Ser}$ analog in $0.1 \%$ BSA injections subcutaneously every $8 \mathrm{~h}$ for $4 \mathrm{~d}$ before death. The number of rats used for each experiment is shown. (Mean $\pm \mathrm{SE}$, $* * P<0.005$.) 

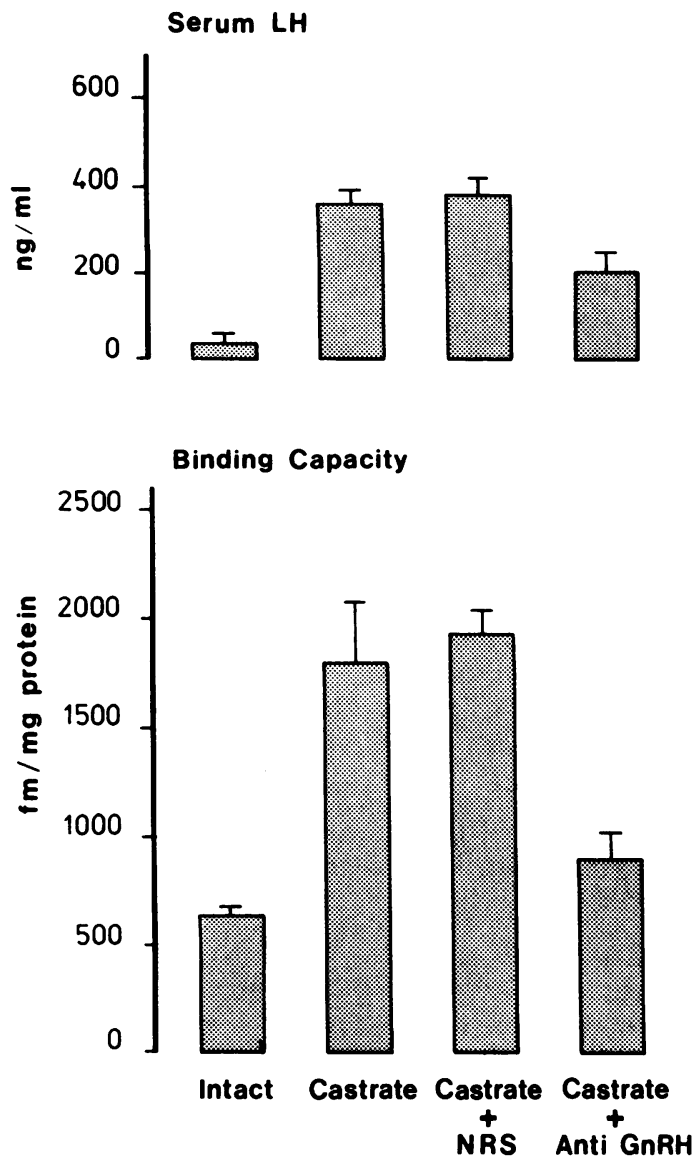

FIGURE 7 Effects of intraperitoneal injection of normal rabbit serum (NRS) or rabbit anti-GnRH serum to adult male rats at the time of castration on $\mathrm{GnRH}$ binding capacity and serum LH. (Mean $\pm \mathrm{SE} ; n=4)$. $(P<0.005$ for GnRH binding capacity and serum LH for anti-GnRH treated castrates compared to castrates without anti-GnRH treatment).

elevated pituitary stalk blood GnRH concentrations after ovariectomy in rhesus monkeys. Additionally, Sherwood and Fink (17) have recently demonstrated elevated hypophyseal portal GnRH concentration $4 \mathrm{~d}$ after ovariectomy and adrenalectomy. Despite higher pituitary stalk plasma $\mathrm{GnRH}$ at $4 \mathrm{~d}$ than $28 \mathrm{~d}$ after ovariectomy-adrenalectomy, serum LH was higher at $28 \mathrm{~d}$; this suggests increased pituitary sensitivity at that time.

To delineate the role of $\mathrm{GnRH}$ in the regulation of its own receptors we treated castrated rats, some of which received testosterone replacement at the time of castration, and intact controls with BSA or D-Ser analog. Our previous studies (40) indicated that treating intact rats with either GnRH or D-Ser analog induced a marked increase in GnRH receptors and "downregulation" of receptor did not occur. Furthermore, a single subcutaneous injection of GnRH caused a significant elevation of $\mathrm{GnRH}$ binding capacity $8 \mathrm{~h}$ later, a time-course consistent with the in vivo responses. As shown in Fig. 6, D-Ser analog treatment increased $\mathrm{GnRH}$ receptors in intact and testosterone-replaced castrates, but did not cause a further increase of the elevated receptor number present in the castrated rats. These results are consistent with the hypothesis that $\mathrm{GnRH}$ receptor number is regulated by endogenous GnRH secretion. Further support for this hypothesis is the suppression of the rise in GnRH receptors after castration by injection of a specific antiserum to GnRH. Both the suppression of LH and reduced receptor numbers seen with anti-GnRH treatment may reflect decreased amounts of active $\mathrm{GnRH}$ reaching the pituitary.

Our observations of increased $\mathrm{GnRH}$ receptors after castration could in part explain the increased pituitary responsiveness to exogenous $\mathrm{GnRH}$ previously reported (4) in castrated rats. If $\mathrm{GnRH}$ receptor number increases with increased GnRH secretion, then decreased $\mathrm{GnRH}$ secretion could be expected to cause decreased $\mathrm{GnRH}$ receptor number and a decline in pituitary responsiveness. Cheung and Davidson (43) and Bishop et al. (44) have demonstrated that castrated rats with lesions in the medial basal hypothalamus, effectively removing all endogenous $\mathrm{GnRH}$, had a dramatic fall in both serum LH and pituitary sensitivity to exogenous GnRH.

We have also shown that testosterone and estradiol replacement at the time of castration prevents the rise in $\mathrm{GnRH}$ receptors induced by castration. Considerable evidence suggests that gonadal steroids influence hypothalamic GnRH secretion. Castration results in a reduction in the medial basal content of $\mathrm{GnRH}$ and testosterone or estradiol replacement restores $\mathrm{GnRH}$ content to intact levels (18-20). In the experiment shown in Fig. 5, serum testosterone was lower $14 \mathrm{~d}$ after castration and testosterone replacement probably due to diminished testosterone release from the implant. At this time, serum LH was elevated and GnRH binding capacity was also increased to values intermediate between intact and castrate levels. This suggests that the lower serum testosterone may have resulted in increased hypothalamic GnRH secretion which, in turn, could have induced the increase in $\mathrm{GnRH}$ receptor number.

In conclusion, we have described a method to assess pituitary membrane GnRH receptors, and using this system we have demonstrated increased GnRH receptor number following castration and treatment with a superagonist GnRH analog. The observed changes in GnRH receptor number correlate well with previous studies of pituitary responsiveness to GnRH. Our data are consistent with endogenous $\mathrm{GnRH}$ positively regulating its own receptor. The effects of gonadal steroids on $\mathrm{GnRH}$ receptor number may be mediated by changes in GnRH secretion. At the present time, however, direct effects of gonadal steroids on the pitui- 
tary have not been excluded, and definition of the exact mechanisms responsible for the rise in $\mathrm{GnRH}$ receptors awaits studies in animals with absent endogenous $\mathrm{GnRH}$ secretion. It seems probable, however, that pituitary membrane $\mathrm{GnRH}$ receptors are regulated in vivo by endogenous hypothalamic $\mathrm{GnRH}$ secretion.

\section{REFERENCES}

1. Gay, V. L., and A. R. Midgley, Jr. 1969. Response of the adult rat to orchidectomy and ovariectomy as determined by LH radioimmunoassay. Endocrinology. 84: 1359- 1364.

2. Kalra, P. S., C. P. Fawcett, L. Krulich, and S. M. McCann. 1973. The effects of gonadal steroids on plasma gonadotropins and prolactin in the rat. Endocrinology. 92: 1256- 1268.

3. Moger, W. H. 1976. Effect of testosterone implants on serum gonadotropin concentrations in the male rat. Biol. Reprod. 14: 665-669.

4. Debeljuk, L., J. A. Vilchez-Martinez, A. Arimura, and A. V. Schally. 1974. Effect of gonadal steroids on the response to LH-RH in intact and castrated male rats. Endocrinology. 94: 1519-1524.

5. Vilchez-Martinez, J. A., A. Arimura, L. Debeljuk, and A. V. Schally. 1974. Biphasic effect of estradiol benzoate on the pituitary responsiveness to LH-RH. Endocrinology. 94: 1300- 1303.

6. Libertun, C., R. Orias, and S. M. McCann. 1974. Biphasic effect of estrogen on the sensitivity of the pituitary of luteinizing hormone-releasing factor (LRF). Endocrinology. 94: 1094-1100

7. Martin, J. E., L. Tyrey, J. W. Everett, and R. E. Fellows. 1974. Estrogen and progesterone modulation of the pituitary response to LRF in the cyclic rat. Endocrinology. 95: $1664-1673$.

8. Gordon, J. H., and S. Reichlin. 1974. Changes in pituitary responsiveness to luteinizing hormone-releasing factor during the rat estrous cycle. Endocrinology. 94: 974-978.

9. Cooper, K. J., C. P. Fawcett, and S. M. McCann. 1975 Variations in pituitary responsiveness to a luteinizing hormone/follicle stimulating hormone releasing factor (LH-RF/FSH-RF) preparation during the rat estrous cycle. Endocrinology. 95: 1293-1299.

10. Aiyer, M. S., G. Fink, and F. Grieg. 1974. Changes in the sensitivity of the pituitary gland to luteinizing hormone releasing factor during the oestrous cycle of the rat. $J$. Endocrinol. 60: 47-64.

11. Legan, S. J., and F. J. Karsch. 1975. Modulation of pituitary responsiveness to luteinizing hormone-releasing factor during the estrous cycle of the rat. Endocrinology. 96: $571-575$.

12. Wang, C. F., B. L. Lasley, A. Lein, and S. S. C. Yen. 1976. The functional changes of the pituitary gonadotrophs during the menstrual cycle. J. Clin. Endocrinol. Metab. 42: 718-728.

13. Hoff, J. D., B. L. Lasley, C. F. Wang, and S. S. C. Yen. 1977. Two pools of pituitary gonadotropin: regulation during the menstrual cycle. J. Clin. Endocrinol. Metab. 44: 302-312.

14. Carmel, P. W., S. Araki, and M. Ferin. 1976. Pituitary stalk portal blood collection in rhesus monkeys: evidence for pulsatile release of gonadotropin releasing hormone (GnRH). Endocrinology. 99: 243-248.
15. Neill, J. D., J. M. Patton, R. A. Dailey, R. C. Tsou, and G. T. Tindall. 1977. Luteinizing hormone releasing hormone in pituitary stalk blood of rhesus monkeys: Relationship to level of LH release. Endocrinology. 101: 430-434.

16. Sarkar, D. K., S. A. Chiappa, G. Fink, and N. M. Sherwood. 1976. Gonadotropin-releasing hormone surge in prooestrous rats. Nature (Lond.). 264: 461-463.

17. Sherwood, N. M., and G. Fink. 1980. Effect of ovariectomy and adrenalectomy on luteinizing hormone-releasing hormone in pituitary stalk blood from female rats. Endocrinology. 106: 363-367.

18. Rudenstein, R. S., H. Bidgeli, M. H. McDonald, and P. J. Snyder. 1979. Administration of gonadal steroids to the castrated male rat prevents a decrease in the release of gonadotropin releasing hormone from the incubated hypothalamus. J. Clin. Invest. 63: 262-267.

19. Kalra, P. S., and S. P. Kalra. 1980. Modulation of hypothalamic luteinizing hormone-releasing hormone levels by intracranial and subcutaneous implants of gonadal steroids in castrated rats: effects of androgen and estrogen antagonists. Endocrinology. 106: 390-397.

20. Shin, S. H., and C. J. Howitt. 1976. Effect of testosterone on hypothalamic LH-RH content. Neuroendocrinology. 21: $165-174$.

21. Drouin, J., L. Lagace, and F. Labrie. 1976. Estradiol-induced increase of the LH responsiveness to LHRH in rat anterior pituitary cells in culture. Endocrinology. 99: 1477-1481.

22. Hseuh, A. J. W., G. F. Erikson, and S. S. C. Yen. 1979. The sensitizing effect of estrogens and catechol estrogen on cultured pituitary cells to luteinizing hormone-releasing hormone: its antagonism by progestins. Endocrinology. 104: 807-813.

23. Schally, A. V., T. W. Redding, and A. Arimura. 1973. Effect of sex steroids on pituitary responses to LH and FSH releasing hormone in vitro. Endocrinology. 93: 893-902.

24. Drouin, J., and F. Labrie. 1976. Selective effect of androgens on $\mathrm{LH}$ and FSH release in anterior pituitary cells in culture. Endocrinology. 98: 1528-1534.

25. Heber, D., and W. D. Odell. 1979. Estrogen modulation of pituitary LHRH receptor in the rat: In vivo and in vitro studies. Am. J. Physiol. 237(2): E136-E141.

26. Spona, J. 1973. LHRH stimulated gonadotrophin release mediated by two distinct pituitary receptors. FEBS (Fed. Eur. Biochem. Soc.) Lett. 35: 59-62.

27. Grant, G., W. Vale, and J. Rivier. 1973. Pituitary binding sites for $\left({ }^{3} \mathrm{H}\right)$-labelled luteinizing hormone releasing factor(LRF).Biochem. Biophys. Res. Commun. 50: 771-778.

28. Marshall, J. C., R. A. Shakespear, and W. D. Odell. 1977. LHRH pituitary plasma membrane binding: the presence of specific binding in other tissues. Clin. Endocrinol. 5: 671-677.

29. Clayton, R. N., R. A. Shakespear, J. A. Duncan, and J. C. Marshall. With appendix by P. J. Munson and D. Rodbard. 1979. Radioiodinated non-degradeable gonadotropin-releasing hormone analogs: new probes for the investigation of pituitary gonadotropin-releasing hormone receptors. Endocrinology. 105: 1369-1381.

30. Koch, Y., T. Baram, E. Hazum, and M. Fridkin. 1977. Resistance to enzymatic degradation of LH-RH analogs possessing increased biological activity. Biochem. Biophys. Res. Commun. 74: 488-491.

31. Clayton, R. N., R. A. Shakespear, J. A. Duncan, and J. C. Marshall. 1979. Luteinizing hormone-releasing hormone inactivation by purified pituitary plasma membranes: effects on receptor binding studies. Endocrinology. 104: $1484-1494$. 
32. Marshall, J. C., and W. D. Odell. 1975. Preparation of biologically active ${ }^{125}$ I LHRH suitable for membrane binding studies. Proc. Soc. Exp. Biol. Med. 149: 351-355.

33. Hauger, R. L., R. P. Kelch, Y. I. Chen, and A. H. Payne. 1977. Testicular receptors for luteinizing hormone after immunoneutralization of gonadotropin releasing hormone in the male rat. J. Endocrinol. 75: 23-32.

34. Lowry, O. H., N. J. Rosebrough, A. L. Farr, and R. J. Randall. 1951. Protein measurement with the Folin phenol reagent. J. Biol. Chem. 193: 265-275.

35. Scatchard, G. 1949. The attraction of proteins for small molecules and ions. Ann. N. Y. Acad. Sci. 41: 660-672.

36. Niswender, G. D., A. R. Midgley, Jr., S. E. Monroe, and L. E. Reichert, Jr. 1968. Radioimmunoassay for rat luteinizing hormone with antiovine $\mathrm{LH}$ serum and ovine LH-131I. Proc. Soc. Exp. Biol. Med. 128: 807-811.

37. Hauger, R. H., Y. D. Chen, R. P. Kelch, and A. H. Payne. 1977. Pituitary regulation of Leydig cell function in the adult male rat. J. Endocrinol. 74: 57-66.

38. Legan, S. J., G. A. Coon, and F. J. Karsch. 1975. Role of estrogens as initiator of daily LH surges in the ovariectomized rat. Endocrinology. 96: 50-56.

39. Savoy-Moore, R. T., N. B. Schwartz, J. A. Duncan, and J. C. Marshall. 1980. Pituitary gonadotropin-releasing hormone receptors during the rat estrous cycle. Science (Wash. D. C.). 209: 942-944.
40. Frager, M., J. Duncan, D. Pieper, S. Tonetta, and J. C. Marshall. 1979. Induction of pituitary membrane GnRH receptors by GnRH and a superagonist GnRH analog. Abstract 432, 61st Meeting of the Endocrine Society.

41. Nansel, D. D., M. S. Aiyer, W. H. Meinzer II, and E. M. Bogdanove. 1979. Rapid, direct effects of castration and androgen treatment on luteinizing hormone-releasing hormone-induced luteinizing hormone release in the phenobarbital treated male rat: examination of the roles direct and indirect androgen feedback mechanisms might play in the physiological control of luteinizing hormone release. Endocrinology. 104: 524-531.

42. Nansel, D. D., and D. F. Trent. 1979. Frequency modulation of pulsatile luteinizing hormone-releasing hormone stimulation can alter the effectiveness of direct androgen feedback on luteinizing hormone-releasing hormoneinduced luteinizing hormone release. Endocrinology. 104: 532-535.

43. Cheung, C. Y., and J. M. Davidson. 1977. Effect of testosterone implants and hypothalamic lesions on luteinizing hormone regulation in the castrated male rat. Endocrinology. 100: 292-302.

44. Bishop, W., C. P. Fawcett, L. Krulich, and S. M. McCann. 1972. Acute and chronic effects of hypothalamic lesions on the release of $\mathrm{FSH}, \mathrm{LH}$, and prolactin in intact and castrated rats. Endocrinology. 91: 643-656. 